Proc. Estonian Acad. Sci. Eng., 2006, 12, 2, 85-95

\title{
Rheology and surface properties of filled dispersions
}

\author{
Eglè Fataraitè ${ }^{\mathrm{a}}$, Pranas Narmontas ${ }^{\mathrm{a}, \mathrm{b}}$, Virginija Jankauskaitè ${ }^{\mathrm{a}}$, \\ Asta Milinavičiūte ${ }^{\mathrm{a}}$ and Algimantas Juraitis ${ }^{\mathrm{b}}$ \\ a Department of Clothing and Polymer Products Technology, Kaunas University of Technology, \\ Studentu 56, LT-51424 Kaunas, Lithuania; egle.fataraite@ktu.lt \\ b Institute of Physical Electronics, Savanoriu 127, LT-50131 Kaunas, Lithuania; \\ pranas.narmontas@ktu.lt
}

Received 24 October 2005, in revised form 1 February 2006

\begin{abstract}
Rheology and wetting properties of commercial water-born dispersion of the copolymer of vinyl ester of a synthetic saturated monocarboxylic acid and acrylate, obtained by emulsion polymerization, have been investigated. For composition modification, $0.8 \mathrm{phr}$ of dibutylglycol as plasticizer and from 0 to $10 \mathrm{phr}$ of $\mathrm{TiO}_{2}$ and $\mathrm{Al}_{2} \mathrm{O}_{3}$ particles as filler were added. It has been shown that dispersion behaviour under shear between two coaxially placed cylinders depends not only on the dispersion composition, but on the shear rate as well. At low shear rates (up to $40 \mathrm{~s}^{-1}$ ), an increase of the viscosity was found, while at higher shear rates dispersion shows pseudoplastic behaviour. Effective amount of $\mathrm{TiO}_{2}$ decreases the intensity of determined anomalies. For pure, plasticized and $\mathrm{TiO}_{2}$ modified dispersions, a tendency to restore viscosity value by decreasing the shear rate was found. This effect for $\mathrm{Al}_{2} \mathrm{O}_{3}$ filled dispersion was insignificant. The results of advancing contact angle measurements showed that an addition of up to $3 \mathrm{phr}$ of mineral filler to the dispersion does not change its wetting properties. Higher amounts of fillers worsen wettability properties.
\end{abstract}

Key words: water-born dispersion, mineral filler, copolymer, rheology, wetting.

\section{INTRODUCTION}

The increasing pressure on the adhesive industry to move away from the use of volatile organic solvents has lead to numerous attempts to produce non-solvent adhesive formulations with equivalent performance to their solvent-containing counterparts. A number of possible routes are available for this replacement but one of particular interest is the use of water-born systems $\left[{ }^{1-3}\right]$.

The usage of such systems can solve many industrial problems and they are finding expanding markets. Aqueous dispersions of polymers offer innovative 
solutions for bio- and nanotechnology, microelectronics and photonics, cosmetics and pharmaceuticals, adhesive industry, etc. $\left.{ }^{4,5}\right]$.

Water-born systems show several advantages compared to the solvent-based ones. The solid content during processing is significantly higher than those of the common solvent-born systems. Furthermore, aqueous dispersions can be processed on the same equipment as solvent-born systems (in contrast to the solventfree hotmelts). That is a big advantage of water-born systems $\left[{ }^{6-8}\right]$.

The behaviour of the dispersions in coating operations, especially when thin $(\sim 2 \mu \mathrm{m})$ layers are formed, depends on their rheological properties. The dependence of viscosity and shear stress on the shear rate determines the behaviour of dispersion during processing. Deviation from the Newtonian response can cause problems in the coating operations using rolls of various construction $\left[{ }^{8,9}\right]$. Especially dilatancy can interfere with the deposition of a smooth and uniform adhesive coating. Severe dilatancy may cause chatter, leaving void spots in places on the web. In reverse roll coating dilatant dispersions require more power and cause more splitting $\left[{ }^{9}\right]$.

Water-born dispersions, based on the copolymer of vinyl ester of synthetic saturated monocarboxylic acid with acrylates, can be successfully used for adhesive layer formation of thin multilayer structures with embossed hologram [ $\left.{ }^{6}\right]$. After adhesive layer formation, such holograms can be bonded to the paper or plastic substrate during hot stamping procedure and used as document security elements $\left[{ }^{4}\right]$. The hot stamping quality significantly depends not only on the regimes of stamping, but also on the adhesive layer formation conditions. It was established that quality of stamps can be increased by adhesive layer modification by fine dispersed $\mathrm{TiO}_{2}$ particles $\left[{ }^{6}\right]$.

It may be supposed that filling with mineral particles can modify dispersion behaviour during its coating procedure using anillox rolls, due to the behaviour of dispersion in the coating operation. The behaviour of dispersion during coating with anillox rolls depends not only on the volume of engravings on their surface of the anillox rolls, but also on the rheological properties of the dispersion and ability to wet the surface $\left.{ }^{[0-12}\right]$.

Thus the aim of this investigation was to evaluate the influence of the nature and content of mineral fillers on the rheology and surface properties of waterborn dispersions.

\section{EXPERIMENTAL}

The commercial water-born dispersion of a copolymer of vinyl ester of a synthetic saturated monocarboxylic acid (VeoVa) and acrylate (A), obtained by emulsion polymerization from FINNDISP (Finland), was used. Total solid content of the copolymer in water medium was $44 \pm 1 \%$ and the average particle size was $0.08 \mu \mathrm{m}$. 
From 0 to 10 parts of titanium dioxide $\left(\mathrm{TiO}_{2}\right)$ and aluminium oxide $\left(\mathrm{Al}_{2} \mathrm{O}_{3}\right)$ per 100 parts (phr) of $\mathrm{VeoVa} / \mathrm{A}$ copolymer was added as the filler. The average particle radius $r$ of $\mathrm{TiO}_{2}$ and $\mathrm{Al}_{2} \mathrm{O}_{3}$ was $0.34 \mu \mathrm{m}$ and $0.8 \mu \mathrm{m}$, respectively.

In order to achieve distribution of the homogenous filler in the dispersion medium, it was predispersed in a small amount of the VeoVa-10/A dispersion. As dispergant, $1 \mathrm{phr}$ of the solution of sodium salt of acrylic acid in water was used. Solid content of the dispergant was $40 \pm 2 \%$. Additionally, $0.8 \mathrm{phr}$ of dibutylglycol as plasticizer was added. Homogenization of the compositions was carried out by mixing at rotational speed of $w=50 \mathrm{~min}^{-1}$ for $10 \mathrm{~min}$.

Multilayer hot stamping foil for paper, produced by Holo 3D S.r.l. (Italy), was used as substrate for the evaluation of the wetting properties. The total thickness of the foil, which consists of aluminium layer, polymer layer for holographic microstructure embossing, release coating and carrier, was $19 \mu \mathrm{m}$.

Rheological measurements was carried out using coaxial rotational viscometer RHEOTEST 2.1 in a wide range of shear rates. Ambient temperature $(T=$ $20 \pm 3^{\circ} \mathrm{C}$ ) was controlled with fluid bath equipped with a rheometer. The flow cell consists of an inner cylinder that rotates at the shear rate of $\dot{\gamma}=0-10^{3} \mathrm{~s}^{-1}$, while the outer concentric cylinder was held stationary. The ratio of the radii of the external and inner cylinders was 1.02. After loading, the dispersion was presheared for $5 \mathrm{~min}$ at an intermediate shear rate to overcome any initial wall effect, occurring due to the plug flow conditions during insertion of the inner cylinder in the outer one.

Measurements of dispersion wettability properties were performed with a dynamic contact angle meter and tensiometer DCAT $_{21}$, produced by Data Physics Instruments $\mathrm{GmbH}$, Filderstadt (Germany). This method is based on the forcebased measurement of the dynamic contact angle of a solid plate as well as on the wetted length, according to the Wilhelmy method. Initially the surface tension of unfilled and filled dispersions was determined using a standard rectangle $(19.90 \times 0.2 \mathrm{~mm})$ Wilhelmy-plate $\mathrm{PT}_{11}$, made of platinum-iridium according to DIN 53914. Only after that the dynamic contact angle between aluminium layer of hot stamping multilayer film and dispersion with known surface tension were determined. It is necessary that during measurements both sides of the solid have the same properties. Due to that two pieces of the multilayer hot stamping foil were bonded with double-sided adhesive tape in such a way that the aluminium layer was outside. Strips of $10 \times 50 \mathrm{~mm}$ were cut. Before fitting, the prepared multilayer sample in the sample holder at the balance perimeter of the sample was measured and surface was cleaned with hexane. The sample vessel with the desired composition was placed into the movable temperature controlled receptacle. The receptacle was moved up at a constant rate of $0.2 \mathrm{~mm} / \mathrm{s}$ in order to establish advancing contact. The moving up of the investigated composition was continued until the final immersion depth was equal to $5 \mathrm{~mm}$ from the liquid level. Six samples were used for measurements and five measurements were made for each sample. 


\section{RESULTS AND DISCUSSION}

The behaviour of unplasticized and plasticized VeoVa/A copolymer dispersions in the wide shear rate range is presented in Fig. 1. The values of viscosity were determined not only in the direction of increase of the shear rate, but also in the opposite direction, i.e. decreasing the shear rate. As it can be seen, independently of the initial preshearing of the composition for $5 \mathrm{~min}$, which must eliminate the effect of walls, the increase of the shear rate from 10 up to $20 \mathrm{~s}^{-1}$ slightly increases viscosity of the dispersion. For the plasticized dispersion $(0.8 \mathrm{phr})$ this effect was found at a shear rate of $30 \mathrm{~s}^{-1}$. As the shear rate reaches values bigger than 20 and $30 \mathrm{~s}^{-1}$, for unplasticized and plasticized VeoVa/A copolymer, respectively, viscosity begins to decrease. Evidently, independently of the shear rate direction (increasing or decreasing) and of the fact that for the pure copolymer the decrease of the shear rate from 20 to $10 \mathrm{~s}^{-1}$ results in a drastic decrease of viscosity, the plasticized dispersion shows lower viscosity than that of the unplasticized copolymer.

The addition of filler particles affects stability and rheological behaviour of the dispersion. Figures 2 and 3 show influence of the nature and content of the filler on the VeoVa/A copolymer dispersion viscosity under various shear rates. In this case the values of viscosity were also determined by the increasing and decreasing shear rates. Despite the filler nature, dispersions show increase of the viscosity at low $\left(10-50 \mathrm{~s}^{-1}\right)$ shear rates. Especially it is evident for compositions containing 5-10 phr of $\mathrm{TiO}_{2}$ (Fig. 2b) and in all cases of $\mathrm{Al}_{2} \mathrm{O}_{3}$ filled dispersions (Fig. 3). This phenomenon can not be related only to the unstable flow regime, because before testing the compositions were presheared. It is probable that in the filled dispersion at low shear rates a network structure is formed, usually characteristic for the solid-like or gel-like structures $\left[{ }^{13}\right]$, which is ruptured at

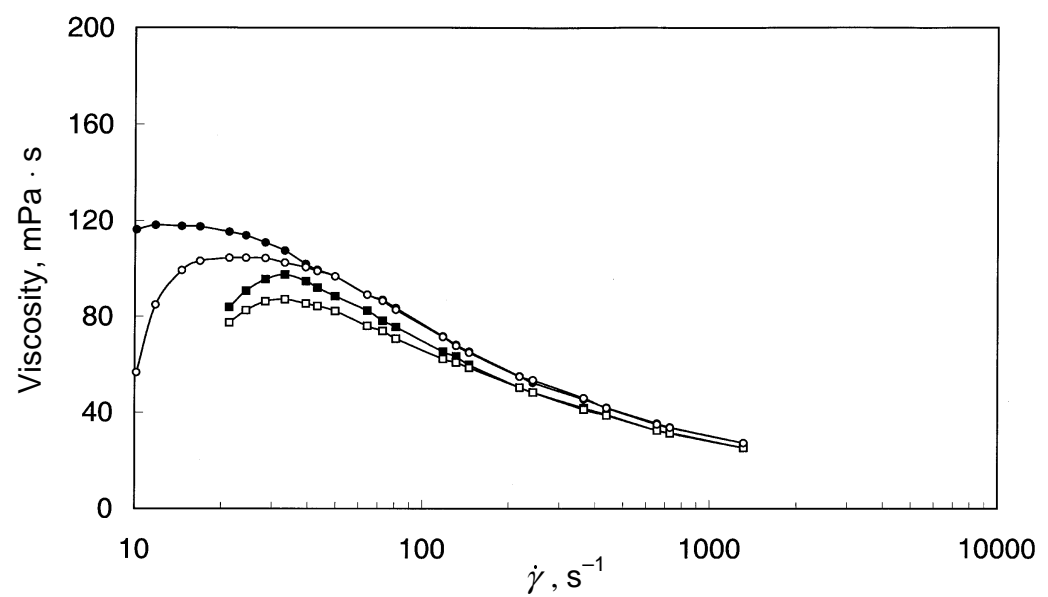

Fig. 1. Dynamic viscosity $\eta$ of pure $(\bullet, \circ)$ and plasticized VeoVa/A $(\bullet, \square)$ copolymer dispersion vs shear rate $\dot{\gamma}(\bullet,-$ - increasing, $\circ, \square-$ decreasing shear rate). 


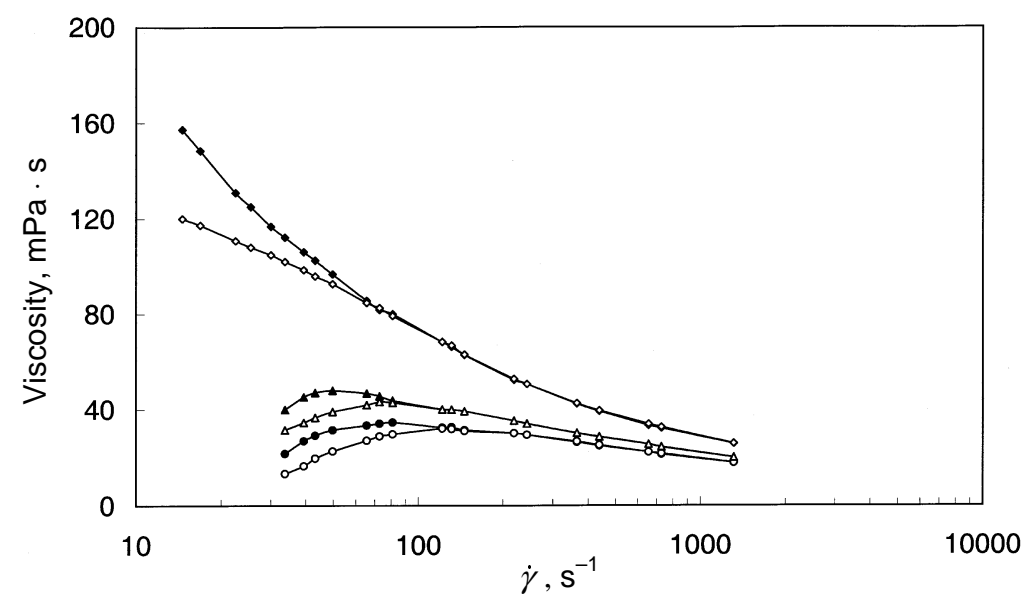

(a)

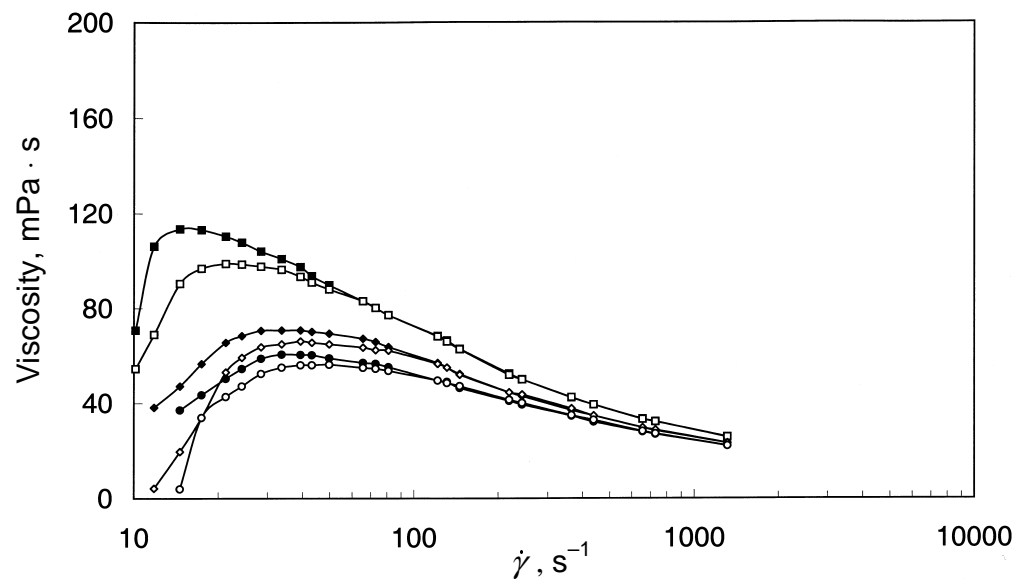

(b)

Fig. 2. Dynamic viscosity $\eta$ of plasticized $\mathrm{VeoVa} / \mathrm{A}$ copolymer vs shear rate $\dot{\gamma}$ by various $\mathrm{TiO}_{2}$ contents $\left(\bullet, \bullet, \bullet-\right.$ increasing, $\square, \diamond, \circ-$ decreasing shear rate); $\mathrm{TiO}_{2}$ content, phr: (a) $-1.0(\boldsymbol{\Delta}, \triangle)$, $2.5(\diamond \diamond), 3.0(\bullet, \circ) ;(\mathrm{b})-5.0(\bullet, \square), 7.0(\bullet, \diamond), 10.0(\bullet, \circ)$.

higher shear rates. A confirmation of this presumption is not only the decrease of viscosity at higher shear rates, but also the absence of the Newtonian plato. Obviously just after initial shear thickening, the shear thinning, indicating pseudoplastic behaviour of dispersions, occurs. Intensity of this effect depends on the nature and content of the filler. To evaluate the character of pseudoplasticity, the shear thinning index $S T I$ was calculated as a ratio of viscosities, determined for the composition at the shear rates of 40 and $1000 \mathrm{~s}^{-1}$, i.e. $S T I=\eta_{40} / \eta_{1000}$. Obtained results are plotted in Fig. 4. As it can be seen, the shear thinning vs filler content has non-monotonous character. Addition of 1.0 and $2.5 \mathrm{phr}$ of $\mathrm{TiO}_{2}$ significantly affects rheological behaviour of the dispersion. The value of STI 


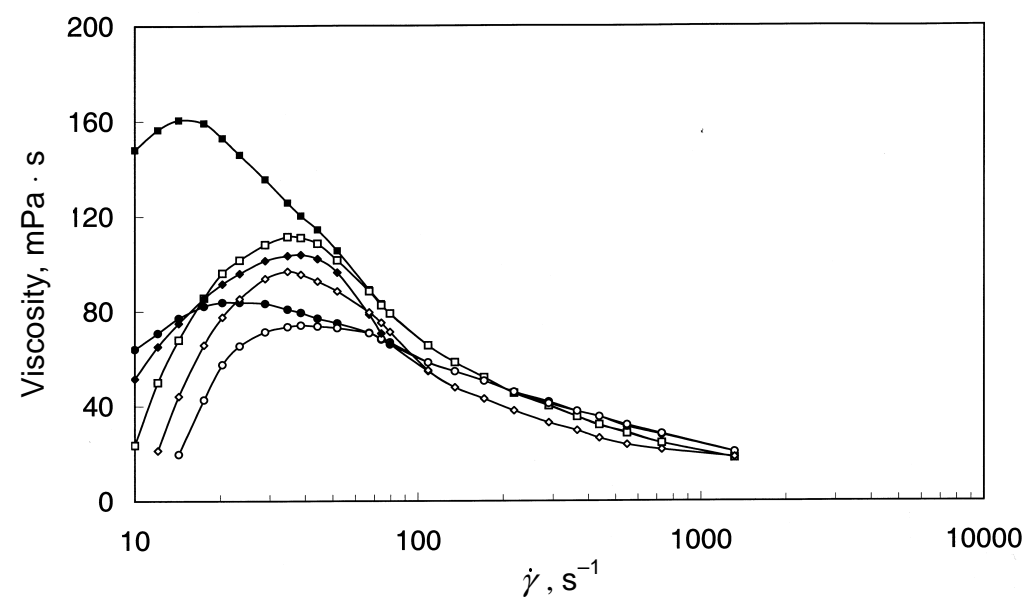

(a)

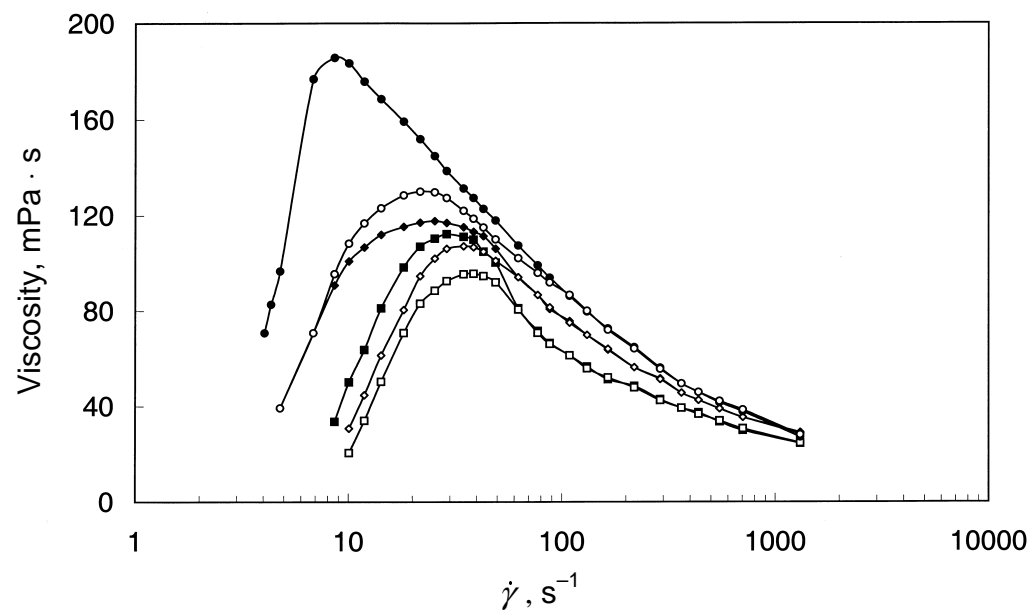

(b)

Fig. 3. Dynamic viscosity $\eta$ of plasticized VeoVa/A copolymer vs shear rate $\dot{\gamma}$ by various $\mathrm{Al}_{2} \mathrm{O}_{3}$ contents $\left(\mathbf{\square}, \bullet, \bullet-\right.$ increasing, $\square, \diamond, \circ-$ decreasing shear rate); $\mathrm{Al}_{2} \mathrm{O}_{3}$ content, phr: (a) $1.0(\mathbf{\square}, \square)$, $2.5(\bullet, \diamond), 3.0(\bullet, \circ)$; (b) $5.0(\bullet, \square), 7.0(\bullet, \diamond), 10.0(\bullet, \circ)$.

close to 1 indicates that dispersion behaviour is close to Newtonian fluids, i.e. viscosity is independent of the shear rate. It means that at the effective $\mathrm{TiO}_{2}$ content, the increase of the shear rate does not significantly influence the flow field, while other $\mathrm{TiO}_{2}$ filled dispersions show STI values close to those of the unfilled dispersion (dashed line in Fig. 4). Expressed pseudoplasticity was found also for the $\mathrm{Al}_{2} \mathrm{O}_{3}$ filled dispersion. Addition of 1.0 and $3.0 \mathrm{phr}$ of this filler decreases viscosity approximately five times when shear rate increases from 40 to $1000 \mathrm{~s}^{-1}$. Only dispersions with $2.5 \mathrm{phr}$ of $\mathrm{Al}_{2} \mathrm{O}_{3}$ show slightly lower STI values than those of the unplasticized or plasticized VeoVa/A copolymer. 


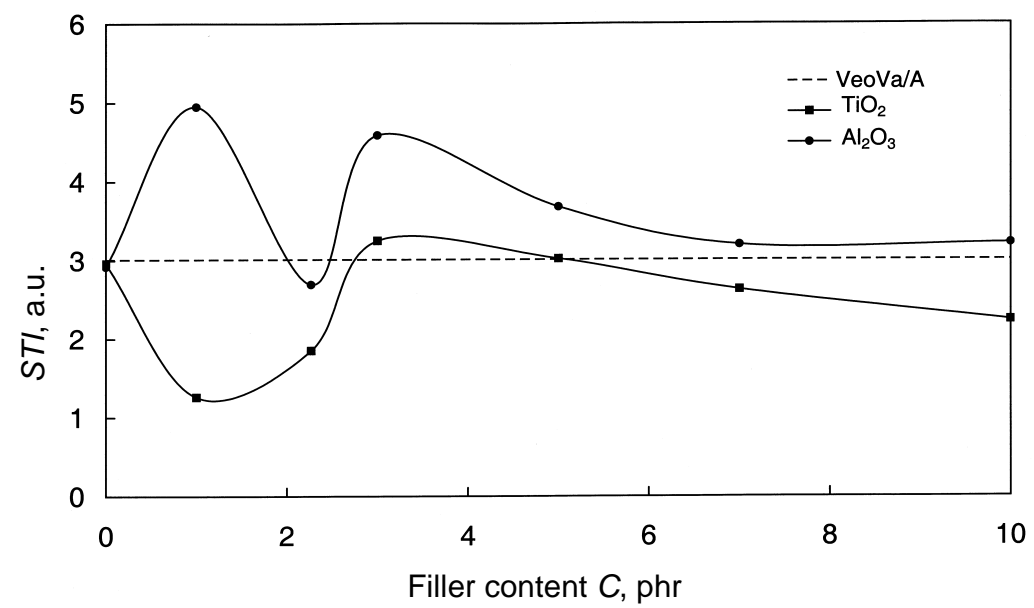

Fig. 4. Influence of the content and nature of the filler on the shear thickening of the $\mathrm{VeoVa} / \mathrm{A}$ copolymer.

Figure 4 shows that the dispersion, containing $\mathrm{Al}_{2} \mathrm{O}_{3}$ particles, shows more expressed shear thinning effect than that with $\mathrm{TiO}_{2}$ particles.

It is probable that the observed heterogeneous behaviour of the dispersion under shear between two concentric cylinders is caused not only by attractive forces between filler particles and Brownian motion of particles of the copolymer. In the filled systems, aggregates or agglomerates of mineral particles gradually break down when shear rate increases and cause pronounced shear thinning. This phenomenon takes place only in the case of reversible systems $\left[{ }^{7,10}\right]$. The ability of reversibility was evaluated by comparing the dispersion viscosity at the same shear rate during the period of increase (I) and decrease (D): $k=\eta_{\mathrm{I}} / \eta_{\mathrm{D}}$ (Fig. 5). It is seen that in the zone of shear rate higher than $100 \mathrm{~s}^{-1}$ for $\mathrm{TiO}_{2}$ and $70 \mathrm{~s}^{-1}$ for $\mathrm{Al}_{2} \mathrm{O}_{3}$ filled dispersions ratio $k$ is equal to 1 . That indicates that in this range neither the filler nor dispersion particles can flocculate or agglomerate.

At intensive decrease of the shear rate, the viscosity begins to increase, but its values are not equal to those obtained by increasing shear rate. This phenomenon is characteristic for thixotropical systems, i.e., under sudden increase of shear rate the viscosity gradually decreases while the structure breaks down to smaller flocks. If shear rate is decreased, the initial structural units are below the new equilibrium size and therefore they gradually grow, causing a gradual increase of viscosity. This effect was observed until the shear rate decreased to $30 \mathrm{~s}^{-1}$. After that dispersion shows a decrease of the viscosity. Independently of this fact, for the unfilled and unplasticized VeoVa/A copolymer dispersion, by decreasing the shear rate to $10 \mathrm{~s}^{-1}$, the viscosity is only insignificantly lower than at the increasing shear rate. In this case ratio $k$ is not higher than 1.5 and only at the shear rate of $10 \mathrm{~s}^{-1}$ it reaches 2 . 


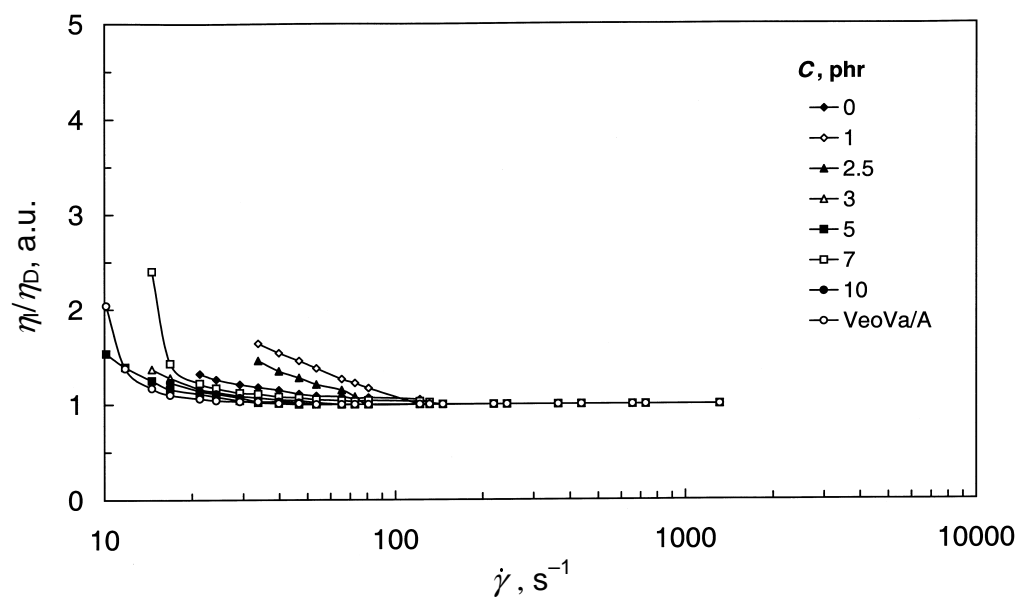

(a)

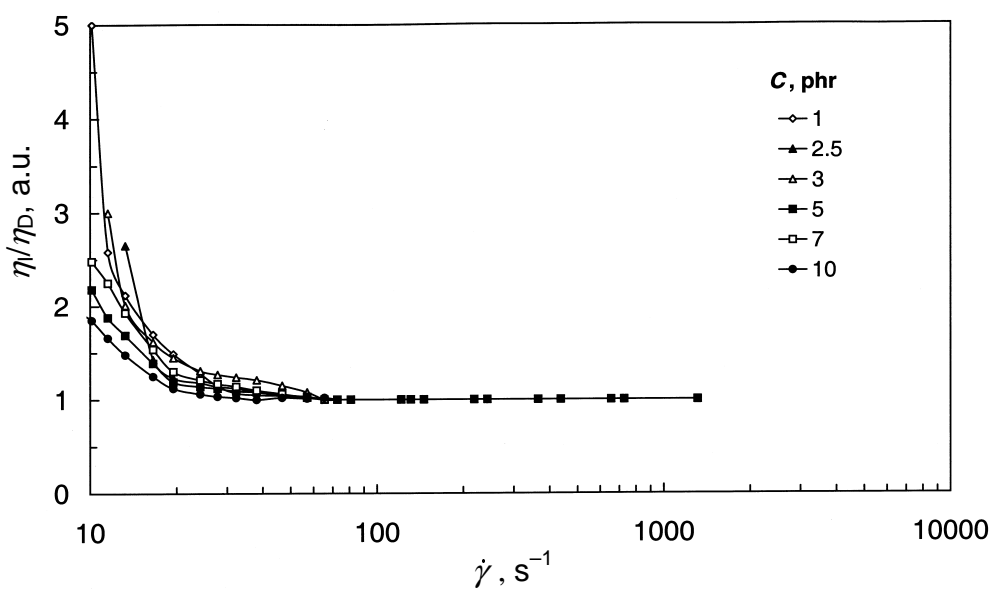

(b)

Fig. 5. Reversibility of the VeoVa/A copolymer $\left(\eta_{\mathrm{I}} / \eta_{\mathrm{D}}\right)$ vs shear rate $\dot{\gamma}$ for filler $\mathrm{TiO}_{2}$ (a) and $\mathrm{Al}_{2} \mathrm{O}_{3}$ (b).

The tendency to restore initial structure was found for dispersions containing $\mathrm{TiO}_{2}$ particles. Plasticized dispersions, modified with this filler, vary from 1.2 to 1.7 (Fig. 5a). Quite different behaviour show dispersions containing $\mathrm{Al}_{2} \mathrm{O}_{3}$. The variation of $k$ from 2 to 5 in the shear rate range from 20 to $10 \mathrm{~s}^{-1}$ indicates that $\mathrm{Al}_{2} \mathrm{O}_{3}$ particles create a specific structure, which is degraded under shear and is unable to return to the initial state.

Obtained anomalies can mainly be related to the particle-particle interactions, which is affected not only by the filler content, but depends also on the particle size. Evidently, the higher particle size (for the dispersion it is equal to $0.08 \mu \mathrm{m}$, for $\mathrm{TiO}_{2}$ and for $\mathrm{Al}_{2} \mathrm{O}_{3}$ it is 0.34 and $0.80 \mu \mathrm{m}$, respectively) the more significant 
is the deviation from the Newtonian fluid curve. It also must be assumed that the viscosity of water-born adhesives depends only on the interaction between particles; but it is independent of the molecular weight of the polymer $\left[{ }^{10}\right]$. Thus obtained results indicate that $\mathrm{Al}_{2} \mathrm{O}_{3}$ particles show higher tendency to initial agglomeration in the dispersion than $\mathrm{TiO}_{2}$ particles.

Another important parameter for the evaluation of the possibility of technological application of the dispersion is the ability to wet the substrate surface. The dependence of the dynamic advancing wetting angle $\theta$ between the dispersion and the aluminium layer of the multilayer holographic foil on the filler content is presented in Fig. 6. Independently of the nature of the filler, the increase of the filler content results in the monotonous decrease of wettability. Experimental points indicate that wetting properties of the dispersion do not change when content of the fillers is not higher than $3 \mathrm{phr}$. Higher filler content results in the decrease of dispersion wetting properties. $\mathrm{Al}_{2} \mathrm{O}_{3}$ modified compositions show slightly better wetting properties than $\mathrm{TiO}_{2}$ filled ones.

Approximation of obtained results by the least squares method shows linear relation (solid lines in Fig. 6) between advancing contact angle $\cos \theta$ and filler content $C$ :

$$
\cos \theta=a C+b,
$$

where $a$ and $b$ are constants.

The parameters of Eq. (1) are presented in Table 1. Close values of them for both fillers indicate that the ability of the dispersion to wet the substrate surface is more affected by the filler content than by its nature.

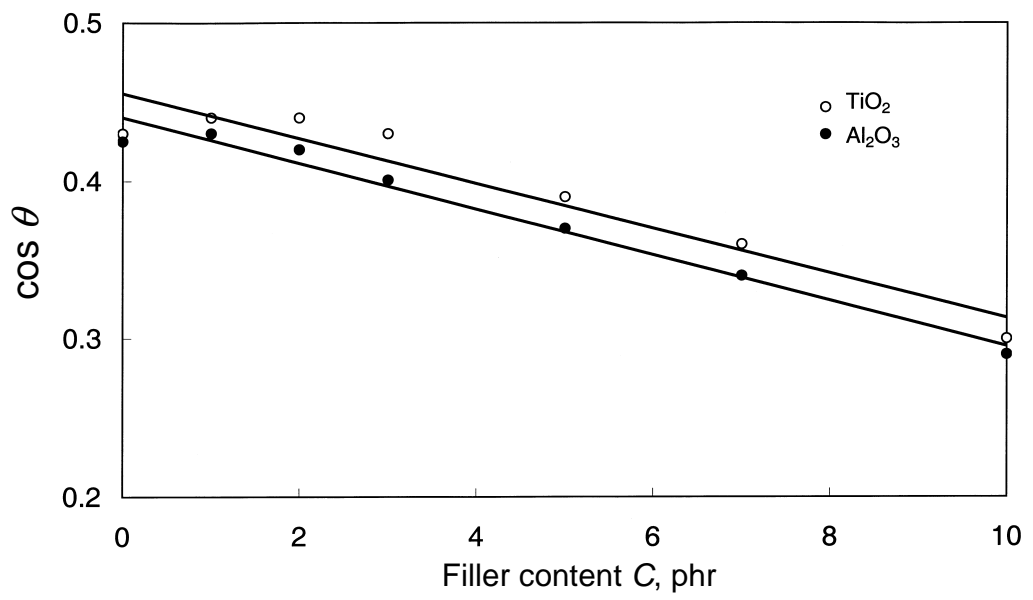

Fig. 6. Effect of the filler content on the advancing angle of adhesive on the surface of hot stamping foil. 
Table 1. Coefficients of Eq. (1) for different fillers

\begin{tabular}{c|c|c|c}
\hline \multirow{2}{*}{ Filler } & \multicolumn{2}{|c|}{ Coefficients } & $\begin{array}{c}\text { Correlation coefficient } \\
R^{2}\end{array}$ \\
\cline { 2 - 3 } & $a$ & $b$ & 0.9198 \\
$\mathrm{TiO}_{2}$ & -0.0142 & 0.4554 & 0.9784 \\
$\mathrm{Al}_{2} \mathrm{O}_{3}$ & -0.0149 & 0.4438 &
\end{tabular}

\section{CONCLUSIONS}

The rheology and wettability of the water-born copolymer of vinyl ester of a synthetic saturated monocarboxylic acid and acrylate (VeoVa/A) dispersion can be modified by disperse filling with mineral highly dispersed $\mathrm{TiO}_{2}$ and $\mathrm{Al}_{2} \mathrm{O}_{3}$ particles.

Addition of filler particles to the dispersion can alert flow field. Intensity of obtained changes depends not only on the filler content and nature, but also on the shear rate. At the shear rate of $40 \mathrm{~s}^{-1}$ an increase of the viscosity was observed. At higher shear rates, investigated compositions show pseudoplastic behaviour. Addition of 1.0-2.5 phr of $\mathrm{TiO}_{2}$ decreases the shear thinning of the dispersion, while $\mathrm{Al}_{2} \mathrm{O}_{3}$ intensifies this process (except dispersions filled with $2.5 \mathrm{phr})$.

In the shear rate range from 10 to $100 \mathrm{~s}^{-1}$ the plasticized as well as the plasticized and $\mathrm{TiO}_{2}$ filled dispersions show the ability to restore the initial viscosity under shear. For $\mathrm{Al}_{2} \mathrm{O}_{3}$ filled dispersions viscosity reversibility is not characteristic.

Low content of filler particles does not worsen wetting properties of the dispersion, while at higher filling degree, monotonous decrease of the ability to wet substrate surface was observed independently of the nature of the filler.

\section{REFERENCES}

1. Bronwen, A. Water based contact adhesives - new developments. Int. J. Adhesion Adhesives, 1998, 18, 15-18.

2. Grisby, W. J., Ferguson, Ch. J., Franich, R. A. and Russell, G. T. Evaluation of latex adhesives containing hydrophobic cores and poly (vinyl acetate) shells: potential to improve poly (vinyl acetate) performance. Int. J. Adhesion Adhesives, 2005, 25, 127-137.

3. Baransten, H. and Gubbels van Hal, W. M. L. G. Environmental Risk Assessment of VeoVa-10. NOTOX project, Final Report. 2003, 19.

4. Van Renesse, R. L. Optical Documents Security. TNO Institute of Applied Physics, 1998.

5. Fricke, H. J. and Maempel, L. Aqueous polymer dispersions for laminating composite films. Adhäsion Kleben Dichten, 1994, 11, 27-33.

6. Narmontas, P., Fataraite, E., Jankauskaite, V. and Guobienè, A. The properties of water born thermoplastic adhesive for hot stamping multilayer films. Mater. Sci. (Medziagotyra), 2004, 10, 321-325.

7. Handbook of Pressure Sensitive Adhesive Technology (Satas, D., ed.). Van Nostrand Reinhold, New York, 1982.

8. Laden, P. Chemistry and Technology of Water Based Inks. Chapman \& Hall, London, 1997. 
9. Fricke, H. J. and Maempel, L. One part aqueous dispersions for glossy film laminating. $J$. Adhes., 1990, 7-8, 32-38.

10. Macosko, Ch. W. Rheology: Principles, Measurements and Applications. VCH Publishers, 1994.

11. Booth, G. L. Coating Equipment and Processes. Lockwood, New York, 1970.

12. Weiss, H. L. Coating and Laminating Machines. Converting Technology Co., Milwaukee, Wisconsin, 1977.

13. Gašic, S., Jovanovič, B. and Janovič, S. The stability of emulsions in the presence of additives. J. Serbian Chem. Soc., 2002, 67, 31-39.

\section{Täidetud dispersioonide reoloogia ja pinnaomadused}

\section{Eglė Fataraitė, Pranas Narmontas, Virginija Jankauskaitè, Asta Milinavičiūtè ja Algimantas Juraitis}

Küllastatud monokarboksüülhappe vinüülestri ja akrülaadi kopolümeeri vesidispersiooni modifitseerimiseks on kasutatud $\mathrm{TiO}_{2}$ või $\mathrm{Al}_{2} \mathrm{O}_{3}$ täiteainena ja dibutüülglükooli plastifikaatorina. Dispersiooni reoloogilise käitumise uurimisel koaksiaalsete silindritega reomeetri abil on leitud erinevate modifikatsioonide reoloogiliste omaduste sõltuvus täiteainete kontsentratsioonist ja nihkedeformatsiooni kiirusest. Kontaktnurga mõõtmise teel on tuvastatud kopolümeeri vesidispersiooni märgamisomaduste sõltuvus täiteainete kontsentratsioonist. 